Historic, Archive Document

Do not assume content reflects current scientific knowledge, policies, or practices. 



\section{Bulletin No. 4}

November 15, 1928

\section{Thomas B. Meehan Co.}

\section{DRESHER, PA. \& I E A $\mathrm{E} Y \mathrm{Y}$}

Telegraph address, Ambler, $\mathbf{P a}$.

Heting $\operatorname{cin}$

\section{READ TERMS}

PACKING. Cost of box and packing additional. When cash is sent with order add 15 per cent. of the bill of goods to cover packing charges.

DELIVERY. To freight and express station, Dresher, $\mathrm{Pa}$.

QUANTITIES. 5 of any one variety and size, furnished at the rate quoted per ten. 25 at the rate quoted per hundred. Less than 5 shrubs of any one variety and size add five cents to the rate per ten. On trees add ten cents to the rate per ten.

RESPONSIBILITY. After goods are placed on board cars here, we assume no responsibility for their safe delivery or any injury caused by delay in delivery by the transportation company.

\section{ACER-Maple}

Per 10 Per 100

200 dasycarpum, Silver, 6 to $8 \mathrm{ft}$

40.00

500 dasycarpum, Silver, 8 to $10 \mathrm{ft}$

5.00

8.50

10.00

400 dasycarpum, Silver, 10 to $12 \mathrm{ft}$

500 dasycarpum, Silver, $11 / 4$ to $11 / 2$ in. cal.

350 dasycarpum, Silver, $11 / 2$ to $13 / 4$ in. ca

17.50

22.50

25 dasycarpum Weirii, cut-leaved, 6 to 8

105 ginnale, $1 \mathrm{I} / 2$ to $2 \mathrm{ft}$

75 ginnale, 2 to $3 \mathrm{ft}$

125 negundo, Box Elder, 6 to $8 \mathrm{ft}$

50 negundo, Box Elder, 8 to $10 \mathrm{ft}$

25 negundo, Box Elder, $11 / 4$ to $11 / 2$ in...............

25 negundo, Box Elder, $11 / 2$ to $13 / 4$ in. ca

15 negundo, Box Elder, $13 / 4$ to 2 in. cal.

1000 platanoides, Norway, 6 to $8 \mathrm{ft}$.

750 platanoides, Norway, 8 to $10 \mathrm{ft}$.

125 platanoides, Norway, $1 \frac{1}{4}$ to $11 / 2$ in. cal

10 polymorphum, green-leaved Japanese, 2 to $3 \mathrm{ft}$

4 polymorphum, green-leaved, Japanese, 4 to $5 \mathrm{ft}$.

15 polymorphum, green-leaved, Japanese, 5 to $6 \mathrm{ft}$.

10 polymorphum dissectum, green cut-leaved, Japanese, 2 to $3 \mathrm{ft}$

7.50

4.00

4.50

5.00

8.50

11.50

13.50

16.50

15.00

22.50

27.50

15.00

25.00

35.00

50.00

\section{ALTHAEA-HIBISCUS-Rose of Sharon}

15 amplissima, 2 to $21 / 2 \mathrm{ft}$.

250 anemonaeflora, double pink, $11 / 2$ to $2 \mathrm{ft}$.

9 anemonaeflora, double pink, 2 to $3 \mathrm{ft}$.

175 Ardens, double blue, $1 \frac{1}{2}$ to $2 \mathrm{ft}$

275 coelestis, single blue, $1 \mathrm{I} / 2$ to $2 \mathrm{ft}$.

100 Duc de Brabant, double red, $11 / 2$ to $2 \mathrm{ft}$..............

200 Duc de Brabant, double red, 2 to $3 \mathrm{ft}$.

8 Duc de Brabant, double red, 3 to $4 \mathrm{ft}$

125 purpurea semi-plena, double purple, $11 / 2$ to $2 \mathrm{ft}$.

34 purpurea semi-plena, double purple, 2 to $3 \mathrm{ft}$.........

200 rubis, single red, $1 \frac{1}{2}$ to $2 \mathrm{ft}$.

210 Snowdrift, single white, $11 / 2$ to $2 \mathrm{ft}$

50 totus albus, single white, $11 / 2$ to $2 \mathrm{ft}$.

\section{AMPELOPSIS-Woodbine}

50 Englemanni, Engleman's Creeper, 2 year.......... $\quad 1.75$

460 Veitchii, Japanese or Boston Ivy, 2 year, No. 1

800 Veitchii, Japanese or Boston Ivy, 2 year, No. 2

AMYGDALUS-Almond

25 nana, double pink, 2 to $3 \mathrm{ft}$.

17 nana double white, 2 to $3 \mathrm{ft}$

\section{ARALIA}

500 pentaphylla (Acanthopanax), 11/2 to $2 \mathrm{ft}$.

1100 pentaphylla (Acanthopanax), 2 to $3 \mathrm{ft}$.

1500 pentaphylla (Acanthopanax), 3 to $4 \mathrm{ft}$

300 pentaphylla (Acanthopanax), 4 to $5 \mathrm{ft}$. 
450 Thunbergii, Japanese, 6 to 12 in.

200 Thunbergii, Japanese, 12 to 15 in

17.50

150.00

700 Thunbergii, Japanese, $1 \frac{1 / 2}{2}$ to $2 \mathrm{ft}$...... leaved Japanese, $2 \mathrm{I} / 2$ to $3 \mathrm{ft}$

65.00

BETULA-Birch

Per 10

193 alba, European White, 5 to $6 \mathrm{ft}$

124 alba, European White, 6 to $8 \mathrm{ft}$....

11 nigra (rubra), Red, 5 to $6 \mathrm{ft}$.

6 nigra (rubra), Red, 6 to $8 \mathrm{ft}$

229 papyrifera, Paper, 5 to $6 \mathrm{ft} \ldots$



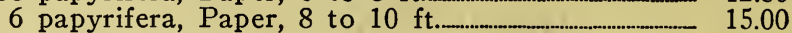

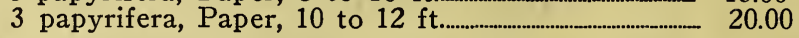

\section{BIGNONIA-Tecoma-Trumpet Vine}

25 radicans, 2 year

\section{BUCKTHORN-See Rhamnus}

BUDDLEIA-Butterfly Bush

100 magnifica, 2 to $3 \mathrm{ft}$.

CALLICARPA-Beauty Fruit

25 purpurea, 2 to $2 \mathrm{r} / 2 \mathrm{ft}$.

CALYCANTHUS-Sweet-shrub

550 floridus, 1 to $1 \mathrm{I} / 2 \mathrm{ft}$.

115 floridus, 2 to $3 \mathrm{ft}$.

\section{CARAGANA-Siberian Pea}

50 arborescens, $11 / 2$ to $2 \mathrm{ft}$.

35 arborescens, 2 to $3 \mathrm{ft}$.

5 arborescens, 3 to $4 \mathrm{ft}$.

$\begin{array}{ll}1.75 & 15.00 \\ 2.25 & 18.00\end{array}$

\section{CATALPA}

28 Bungei, 5 to $5 \mathrm{r} / 2 \mathrm{ft}$. stem, 2 year head.

36 Bungei, $5 \mathrm{x} / 2$ to $6 \mathrm{ft}$. stem, 2 year head.

46 Bungei, $6 \mathrm{ft}$. stem, 2 year head...

18.00

\section{CELASTRUS-Bittersweet}

100 orbiculatus, Japanese, $1 \mathrm{t} / 2$ to $2 \mathrm{ft}$.

15 scandens, American, $11 / 2$ to $2 \mathrm{ft}$.

18.00

CERCIS-Red-bud, Judas Tree

1425 Canadensis, 2 to $3 \mathrm{ft}$

380 Canadensis, 3 to $4 \mathrm{ft}$

200 Canadensis, 4 to $5 \mathrm{ft}$...

25 Canadensis, 5 to $6 \mathrm{ft}$. 3 Canadensis, TREE FORM, 2 to $3 \mathrm{ft}$.

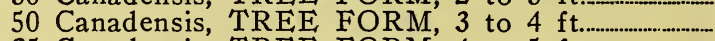

25 Canadensis, TREE FORM, 4 to $5 \mathrm{ft}$.

160 Japonica, Japanese, 1 to $11 / 2 \mathrm{ft}$.

38 Japonica, Japanese, $11 / 2$ to $2 \mathrm{ft}$

\section{CORNUS-Dogwood}

500 alba Siberica, red-stemmed, $1 \mathrm{r} / 2$ to $2 \mathrm{ft}$.

850 alba Siberica, red-stemmed, 2 to $3 \mathrm{ft}$.

365 alba Siberica, red-stemmed, 3 to $4 \mathrm{ft}$.

1135 florida, white flowering, 2 to $3 \mathrm{ft}$.

570 florida, white flowering, 3 to $4 \mathrm{ft}$..

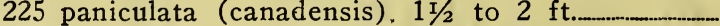

350 paniculata (canadensis), 2 to $3 \mathrm{ft}$...

50 paniculata (canadensis), 3 to $4 \mathrm{ft}$.

5 paniculata (canadensis), 4 to $5 \mathrm{ft}$

50 sericea (amomum), silky, 2 to $3 \mathrm{ft}$.

100 sericea (amomum), silky, 3 to $4 \mathrm{ft}$.

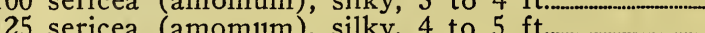

45 Spaethi aurea, golden-leaved, $11 / 2$ to $2 \mathrm{ft} . . . . \ldots \ldots$

110 Spaethi aurea, golden-leaved, 2 to $3 \mathrm{ft}$.

630 stolonifera lutea, yellow-stemmed, $11 / 2$ to $2 \mathrm{ft}$...

40 stolonifera lutea, yellow-stemmed, 2 to $3 \mathrm{ft}$...............

CYDONIA-Japanese Quince, Fire-bush 1000 Japonica, $11 / 2$ to $2 \mathrm{ft}$. 
THOMAS B. MEEHAN CO., DRESHER, PA., BULLETIN NO. 4

\section{DEUTZIA}

275 candidissima, double white, $11 / 2$ to $2 \mathrm{ft}$.

300 candidissima, double white, 2 to $3 \mathrm{ft}$.

100 candidissima, double white, 3 to $4 \mathrm{ft}$.

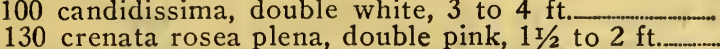

120 Pride of Rochester, double pink, $11 / 2$ to $2 \mathrm{ft}$

225 Pride of Rochester, double pink, 3 to $4 \mathrm{ft}$.

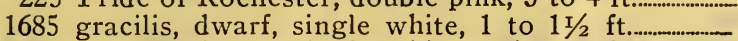

2330 gracilis, dwarf, single white, $11 / 2$ to $2 \mathrm{ft}$.

510 gracilis, dwarf, single white, 2 to $2 \mathrm{r} / 2 \mathrm{ft} . . . . . . . . . .$.

425 gracilis rosea, dwarf, single pink, $11 / 2$ to $2 \mathrm{ft}$.

150 gracilis rosea, dwarf, single pink 2 to $21 / 2 \mathrm{ft}$....

2000 Lemoinei, medium dwarf, single white, $11 / 2$ to $2 \mathrm{ft}$.

1200 Lemoinei, medium dwarf, single white, 2 to $2 \mathrm{I} / 2 \mathrm{ft}$.

\section{ELEAGNUS}

40 angustifolia, Russian Olive, $1 \mathrm{t} / 2$ to $2 \mathrm{ft}$.

75 angustifolia, Russian Olive, 2 to $3 \mathrm{ft}$..

\section{EUONYMUS}

803 alatus, Japanese, $1 \mathrm{r} / 2$ to $2 \mathrm{ft}$.

726 alatus, Japanese, 2 to $3 \mathrm{ft}$.

200 alatus, Japanese, 3 to $4 \mathrm{ft}$

2050 radicans, creeping, 6 to 9 in.

825 radicans, creeping, 9 to 12 in.

195 Sieboldi, $1 \mathrm{I} / 2$ to $2 \mathrm{ft}$.

135 vegetus, Evergreen Bittersweet, 6 to 12 in..............

\section{EXOCHORDA-Pearl Bush}

19 grandiflora, $1 \mathrm{I} / 2$ to $2 \mathrm{ft}$

25 grandiflora, 2 to $3 \mathrm{ft}$

\section{FORSYTHEA-Golden Bell}

890 Fortunei, 3 to $4 \mathrm{ft}$

150 Fortunei, 4 to $5 \mathrm{ft}$

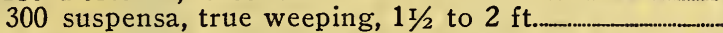

90 suspensa, true weeping, 2 to $3 \mathrm{ft}$...

435 viridissima, $1 \mathrm{I} / 2$ to $2 \mathrm{f}$

275 viridissima, 2 to $3 \mathrm{ft}$

\section{FRAXINUS-Ash}

200 viridis (lanceolata), Green Ash, 6 to $8 \mathrm{ft}$.

200 viridis (lanceolata), Green Ash, 8 to $10 \mathrm{ft}$

59 viridis (lanceolata), Green Ash, $11 / 4$ to $1 \frac{1}{2} \mathrm{in}$. cal. 12.50

19 viridis (lanceolata), Green Ash, $1 \frac{1}{2}$ to $13 / 4$ in. cal. 17.50

10 viridis (lanceolata), Green Ash, $13 / 4$ to 2 in. cal... 22.50

\section{GINGKO-Maidenhair Tree}

76 biloba, 5 to $6 \mathrm{ft}$.

19 biloba, $1 \frac{1}{4}$ to $11 / 2$ in. cal

7 biloba, $1 \frac{1 / 2}{2}$ to $13 / 4$ in. cal..

12.50 25.00 30.00

\section{HALESIA-Silver Bell}

60 tetraptera, 2 to $3 \mathrm{ft}$

100 tetraptera, 3 to $4 \mathrm{ft}$

20 tetraptera, 4 to $5 \mathrm{ft} \ldots$

20 tetraptera, 5 to $6 \mathrm{f}$

4.50

5.50

6.50

7.50

HAMAMELIS-Witch Hazel

450 Virginica, $1 \mathrm{I} / 2$ to $2 \mathrm{ft}$

1390 Virginica, 2 to $3 \mathrm{ft}$.

1150 Virginica, 3 to $4 \mathrm{ft}$

100 Virginica, 4 to $5 \mathrm{ft}$

25 Virginica, 5 to $6 \mathrm{ft}$

HAWTHORN-See Crataegus

\section{HIBISCUS-See Althaea and Mallow}

\section{HONEYSUCKLE-See Lonicera}

\section{HYDRANGEA}

275 arborescens grandiflora, $11 / 2$ to $2 \mathrm{ft}$

335 arborescens grandiflora, 2 to $3 \mathrm{ft}$

675 paniculata, type (Not P. G.) $11 / 2$ to 2 ft.

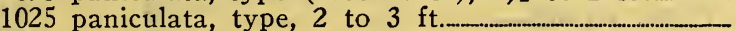

300 paniculata, type, 3 to $4 \mathrm{ft}$.

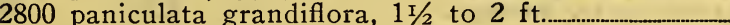

3900 paniculata grandiflora, 2 to $3 \mathrm{ft}$...

1450 paniculata grandiflora, 3 to $3 \mathrm{I} / \mathrm{ft}$

145 paniculata grandiflora, TREE FORM, 2 to $3 \mathrm{ft}$.

\section{ILEX-Winterberry}

25 verticillata, 2 to $3 \mathrm{ft}$.

3.00

4.00

5.00

6.50

8.50
Per 100

15.00

18.00

22.00

15.00

15.00

22.00

16.00

25.00

35.00

30.00

40.00

18.00

22.00

16.00

20.00

35.00

50.00

65.00

16.00

20.00

65.00

25.00

20.00

25.00

25.00

30.00

20.00

25.00

16.00

20.00

50.00

75.00

100.00

100.00

40.00

50.00

25.00

35.00

45.00

60.00

75.00

ITEA-Sweetspire

20 Virginica, $1 \mathrm{I} / 2$ to $2 \mathrm{ft}$.

50 Virginica, 2 to $3 \mathrm{ft}$. 
THOMAS B. MEEHAN CO., DRESHER, PA., BULLETIN NO. 4

\section{JASMINUM}

370 nudiflorum, yellow, $1 \mathrm{r} / 2$ to $2 \mathrm{ft}$

Per 10

2.50

Per 100

JUGLANS-Walnut

53 nigra, Black Walnut, 4 to $5 \mathrm{ft}$.

44 nigra, Black Walnut, 5 to $6 \mathrm{ft}$.
20 nigra, Black Walnut, 6 to $8 \mathrm{ft}$.

\section{KERRIA-Corchorus}

300 Japonica, single, $1 \mathrm{~T} / 2$ to $2 \mathrm{ft}$.

725 Japonica, single, 2 to $3 \mathrm{ft}$.

70 Japonica, double, 2 to $3 \mathrm{ft}$.

100 Japonica, double, 3 to $4 \mathrm{ft}$

\section{LIGUSTRUM-Privet}

5300 Amoor North, $11 / 2$ to $2 \mathrm{ft}$

4500 Amoor North, 2 to $3 \mathrm{ft}$.

2100 Amoor North, 3 to $4 \mathrm{ft}$

Ibota, drooping, $1 \mathrm{I} / 2$ to $2 \mathrm{ft}$............ 1.00

1225 Ibota, drooping, 2 to $3 \mathrm{ft}$....................- 1.25

1770 Ibota, drooping, 3 to $4 \mathrm{ft}$.___.... 2.00

375 Regelianum, true, 1 to $1 \frac{1}{2} \mathrm{ft}$. broad 1.25

1690 Regelianum, true, $1 \mathrm{t} / 2$ to $2 \mathrm{ft}$. broad 1.50

1000 Regelianum, true. 2 to $2 \mathrm{r} / 2 \mathrm{ft}$. broad 2.25

1000 ovalifolium, California, $11 / 2$ to $2 \mathrm{ft}$. .65

2000 ovalifolium, California, 2 to $3 \mathrm{ft}$..... $\quad .75$

LINDERA-Spice 'Bush

850 benzoin, $1 \frac{1}{2}$ to $2 \mathrm{ft}$

250 benzoin, 2 to $3 \mathrm{ft}$.

LIOUIDAMBAR-Sweet Gum

3 styraciflua, 6 to $8 \mathrm{ft}$

8 styraciflua, $11 / 4$ to $11 / 2$ in. cal.

LIRIODENDRON-Tulip Tree

353 tulipifera, 4 to $5 \mathrm{ft}$..

256 tulipifera, 5 to $6 \mathrm{ft}$.

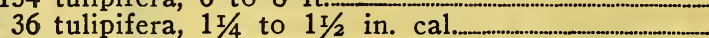



22 tulipifera, $13 / 4$ to 2 in. cal.

LONICERA-Bush Honeysuckle

25 atrosanguinea, pink, 2 to $3 \mathrm{ft}$.

70 atrosanguinea, deep pink, 3 to $4 \mathrm{ft}$

50 bella albida, white, 2 to $3 \mathrm{ft}$.

250 bella albida, white, 3 to $4 \mathrm{ft}$

75 bella albida, white, 4 to $5 \mathrm{ft}$.

160 fragrantissima, white, $11 / 2$ to $2 \mathrm{ft}$

70 fragrantissima, white, 2 to $3 \mathrm{ft}$..

100 fragrantissima, white, 3 to $4 \mathrm{ft}$

300 Morrowii, drooping, white, $11 / 2$ to $2 \mathrm{ft}$._._._._......

700 Morrowii, drooping, white, 2 to $3 \mathrm{ft}$..

100 Morrowii, drooping, white, 3 to $4 \mathrm{ft}$

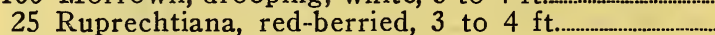

125 Ruprechtiana, red-berried, 4 to $5 \mathrm{ft}$.

275 tatarica alba, white, $1 \mathrm{r} / 2$ to $2 \mathrm{ft}$.

430 tatarica alba, white, 2 to $3 \mathrm{ft}$.

327 tatarica alba, white, 3 to 4 ft

5 ft.

41 tatarica rubra, 2 to $3 \mathrm{ft}$

75 tatarica rubra, 3 to $4 \mathrm{ft}$.

130 grandiflora rosea, 1 to $1 \mathrm{t} / 2 \mathrm{ft}$

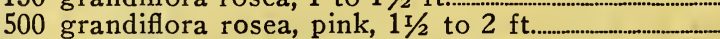

190 grandiflora rosea, pink, 2 to $3 \mathrm{ft}$

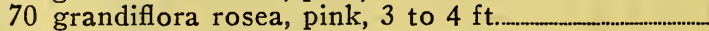

75 tatarica, yellow-berried, 3 to $4 \mathrm{ft}$.

125 tatarica, yellow-berried, 3 to 4 ft.......................................

HONEYSUCKLE-Vines

75 Halleana, 2 year

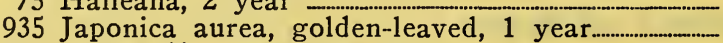

350 Scarlet Trumpet, 2 year.

645 Scarlet Trumpet, 3 year.

LYCIUM-Matrimony Vine

350 barbarum (Chinensis), $11 / 2$ to $2 \mathrm{ft}$

MEEHAN'S MALTOW MARVEIS-Giant

600 Pink, 2-year roots, strong

400 Red, 2-year roots, strong

600 White, 2-year roots, strong.

150 Crimson, 2 -year roots, strong

MALUS-Flowering Crab

30 Ioensis, Bechtel's, 3 to $4 \mathrm{ft}$........................................

MORUS-Mulberry

40 Tea's Weeping, 2-year heads..................................................... 25.00

4.00

5.00

6.50

$3.00 \quad 25.00$

$4.00 \quad 35.00$

$4.00 \quad 35.00$

$4.50 \quad 40.00$

Per 100 Per 1000

$6.00 \quad 50.00$

$8.00 \div \quad 70.00$

$12.00 \quad 100.00$

$7.50 \quad 60.00$
10.00

$10.00 \quad 80.00$

$17.50 \quad 140.00$

$10.00 \quad 80.00$

$12.00 \quad 100.00$

$18.00 \quad 150.00$

$\begin{array}{ll}4.50 & 35.00\end{array}$

$5.50 \quad 45.00$

Per 10 Per 100

$3.50 \quad 30.00$

$4.50 \quad 40.00$

15.00

20.00

5.50

7.50

10.00

15.00

17.50

20.00

50.00

70.00

90.00

$2.00 \quad 16.00$

$2.50 \quad 20.00$

$2.00 \quad 16.00$

$2.50 \quad 20.00$

$3.50 \quad 30.00$

$1.85 \quad 15.00$

18.00

25.00

13.00

16.00

20.00

20.00

30.00

12.00

16.00

20.00

30.00

18.00

25.00

10.00

12.00

16.00

20.00

20.00

30.00

20.00

13.00

20.00

25.00

$1.35 \quad 10.00$

Marsh Mallow

$1.85 \quad 15.00$

$2.25-18.00$

$1.85 \quad 15.00$

$2.50 \quad 20.00$

$6.50 \quad 60.00$

225.00

4.00

ICA-Wax Myrtle

YDENDRON-Sourwood

20 arboreum, 2 to $3 \mathrm{ft}$.

50 arboreum, 3 to $4 \mathrm{ft}$. 
THOMAS B. MEEHAN CO., DRESHER, PA., BULLETIN NO. 4

PERSICA-Flowering Peach

50 Double pink, 4 to $5 \mathrm{ft}$

75 Double red, 4 to $5 \mathrm{ft}$.

Per 10

5.50

Per 100

25 Double white, 4 to $5 \mathrm{ft}$

$5.50 \quad 50.00$

$5.50 \quad 50.00$

PHILADELPHUS-Syringa-Mock Orange

180 coronarius, $11 / 2$ to $2 \mathrm{ft}$.

1.85

2.75

200 grandiflorus, large-flowered, $11 / 2$ to $2 \mathrm{ft} \ldots \ldots \ldots \ldots-\ldots$

500 grandiflorus, large-flowered, 2 to $3 \mathrm{ft}$...

150 grandiflorus, large-flowered, 3 to $4 \mathrm{ft}$

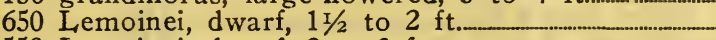

550 Lemoinei, dwarf, 2 to $3 \mathrm{ft}$..

700 Mont Blanc, 2 to $3 \mathrm{ft}$.

800 Mont Blanc, 3 to $4 \mathrm{ft} . \ldots \ldots$

300 Mont Blanc, 4 to $5 \mathrm{ft}$.

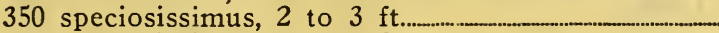

600 speciosissimus, 3 to $4 \mathrm{ft}$

45 speciosissimus, 4 to $5 \mathrm{ft}$..

This is one of the best of the large flowering sort

100 virginale, 2 to $3 \mathrm{ft}$.

2.25

2.75

2.00

2.75

2.00

2.50

3.50

2.00

2.50

3.50

4.00

15.00

22.00

15.00

18.00

22.00

16.00

22.00

16.00

20.00

30.00

16.00

20.00

30.00

35.00

PLATANUS-Plane-European Sycamore

100 Orientalis, 8 to $10 \mathrm{ft}$

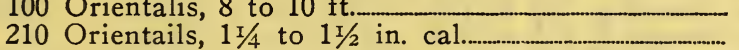

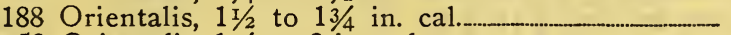



\section{POPULUS-Poplar}

1800 fastigiata, Lombardy, 6 to $8 \mathrm{ft}$.

500 fastigiata, Lombardy, 8 to $10 \mathrm{ft}$

450 fastigiata, Lombardy, $11 / 4$ to $11 / 2$ in. cal

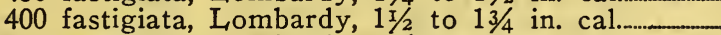

300 fastigiata, Lombardy, $13 / 4$ to $2 \mathrm{in}$. cal.

125 monolifera, Carolina, 6 to $8 \mathrm{ft}$

150 monolifera, Carolina, 8 to $10 \mathrm{ft}$

125 monolifera, Carolina, $11 / 4$ to $11 / 2$ in. cal..........................

75 monolifera, Carolina, $13 / 4$ to 2 in. cal.

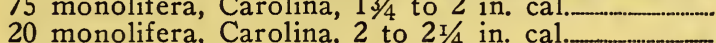

7 monolifera, Carolina, $21 / 4$ to $21 / 2$ in $c^{2}$ l.

\section{PRIVET-See Ligustrum}

\section{PRUNUS-Flowering Plum}

25 triloba, double pink, 2 to $3 \mathrm{ft}$.

250.00

35.00

45.00

70.00

95.00

125.00

30.00

40.00

50.00

85.00

125.00

\section{QUERCUS-Oak}

20 alba, white, 4 to $5 \mathrm{ft}$.

19 alba, white, 5 to $6 \mathrm{ft}$

4 alba, white, 6 to $8 \mathrm{ft}$.

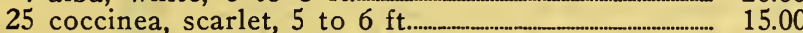

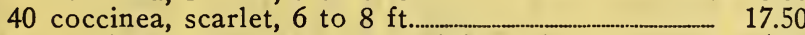

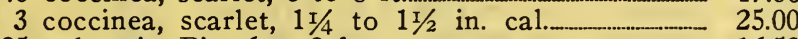

25 palustris, Pin, 6 to $8 \mathrm{ft}$._........ 16.50

43 palustris, Pin, $1 \frac{1}{4}$ to $11 / 2$ in. cal._............. 25.00

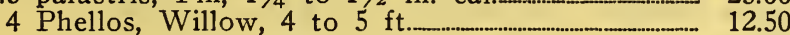

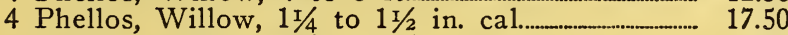

2 Phellos, Willow, $1 \frac{1}{2}$ to $13 / 4$ in. cal................... 25.00

RHAMNUS-Buckthorn

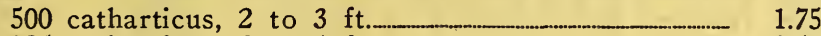

125 catharticus, 3 to $4 \mathrm{ft} \ldots$

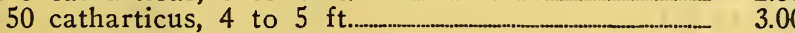

RHODOTYPOS-White Kerria

350 kerroides, 2 to $3 \mathrm{ft}$.

265 kerroides, 3 to $4 \mathrm{ft}$.

\section{RHUS-Sumac}

215 copallina, shining, 2 to $3 \mathrm{ft}$.

225 copallina, shining, 3 to $4 \mathrm{ft}$.

35 copallina, shining, 4 to $5 \mathrm{ft}$.

10 copallina, shining, 5 to $6 \mathrm{ft}$.

40.00

10 cotinus, Smoke br

15 cotinus, Smoke bush, 2 to $3 \mathrm{ft}$......................

10 cotinus, Smoke bush, 3 to $4 \mathrm{ft}$..... 7.50

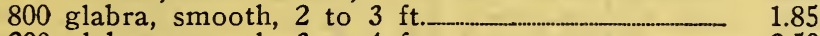

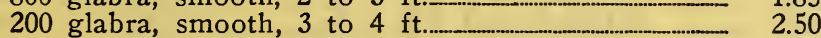

400 typhina, Staghorn, 2 to $3 \mathrm{ft}$...................................... $\quad 1.85$

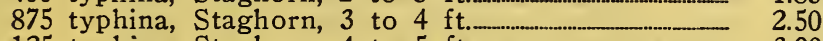

125 typhina, Staghorn, 4 to $5 \mathrm{ft}$. $\ldots \ldots$

125.00

150.00

135.00

15.00

20.00

25.00

25.00

35.00

ROBINIA-Locust

25 hispida rosea, pink flowering, 2 to $3 \mathrm{ft}$., bush form

44 pseudo-acacia, yellow or black, 5 to $6 \mathrm{ft}$.

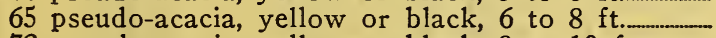

72 pseudo-acacia, yellow or black, 8 to $10 \mathrm{ft}$.......... 7.50

50 pseudo-acacia, yellow or black, $1 \frac{1}{4}$ to $11 / 2$ in. cal. 10.00

15 pseudo-acacia, yellow or black, $1 \frac{1}{2}$ to $13 / 4$ in. cal. 12.50 
75 multiflora Japonica, white, $1 \mathrm{I} / 2$ to $2 \mathrm{ft}$ -

112 multiflora Japonica, white, 2 to $3 \mathrm{ft}$....

250 multiflora Japonica, white, 3 to $4 \mathrm{ft}$..._._.

250 rubiginosa, Sweet Briar, 2 to $3 \mathrm{ft}$.

125 rubiginosa, Sweet Briar, 3 to $4 \mathrm{ft}$.

300 rugosa, pink, $1 \mathrm{I} / 2$ to $2 \mathrm{ft}$

120 rugosa, pink, 2 to $3 \mathrm{ft}$.

20 rugosa alba, white, 2 to $3 \mathrm{ft}$

$\begin{array}{ll}2.00 & 16.00 \\ 2.50 & 20.00\end{array}$

$3.00 \quad 25.00$

$3.00 \quad 25.00$

$3.50 \quad 30.00$

10 rugosa alba, white, 3 to $4 \mathrm{ft}$

50 setigera, Prairie rose, 2 to $3 \mathrm{ft}$.

30.00

$\begin{array}{ll}2.00 & 16.00 \\ 2.50 & 20.00\end{array}$

75 Wichuraiana, Memorial rose $11 / 2$ to $2 \mathrm{ft}$

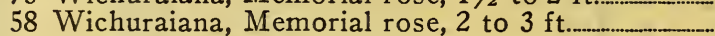

3.50

4.00

2.50

2.50

20.00

20.00

$3.00 \quad 25.00$

\section{SALISBURIA-See Ginkgo}

\section{SALIX-Willow}

205 Babylonica, Weeping, 6 to $8 \mathrm{ft}$.

372 Babyloncia, Weeping, 8 to $10 \mathrm{ft}$

378 Babylonica, Weeping, 10 to $12 \mathrm{ft}$

255 Babylonica, Weeping, $11 / 4$ to $11 / 2$ in. cal.



6 Babylonica, Weeping, $13 / 4$ to 2 in. cal.

175 Britzensis, red barked 4 to $5 \mathrm{ft}$. cal

375 Britzensis, red barked, 5 to $6 \mathrm{ft} . \ldots \ldots$

400 Britzensis, red barked, 6 to $8 \mathrm{ft}$.

11 caprea, Pussy Willow, 2 to $3 \mathrm{ft}$

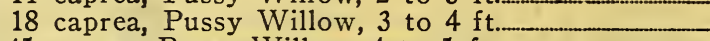

45 caprea, Pussy Willow, 4 to $5 \mathrm{ft}$.

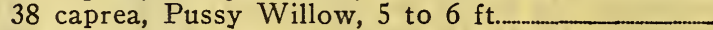

300 pentranda, laurel-leaved, 4 to $5 \mathrm{ft}$

375 pentandra, laurel-leaved, 5 to $6 \mathrm{ft}$._.

7 pentandra, laurel-leaved, 6 to $8 \mathrm{ft}$.

175 vitellina aurea, golden-barked, 4 to $5 \mathrm{ft}$. -

150 vitellina aurea, golden-barked, 5 to $6 \mathrm{ft}$._-___-

10 vitellina aurea, golden-barked, 6 to $8 \mathrm{ft}$.

$\begin{array}{rr}6.50 & 60.00 \\ 8.50 & 80.00 \\ 12.50 & 100.00 \\ 15.00 & 125.00 \\ 17.50 & 150.00 \\ 20.00 & \\ 3.50 & 25.00 \\ 4.00 & 30.00 \\ 5.00 & 40.00 \\ 2.50 & \\ 3.00 & \\ 3.50 & \\ 4.00 & \\ 3.50 & 25.00 \\ 4.00 & 30.00 \\ 5.00 & 40.00 \\ 3.50 & 25.00 \\ 4.00 & 30.00\end{array}$

\section{SAMBUCUS-Elderberry}

225 aurea, golden-leaved, $1 \mathrm{~T} / 2$ to $2 \mathrm{ft}$

350 aurea, golden-leaved, 2 to $3 \mathrm{ft}$

150 aurea golden-leaved 3 to $4 \mathrm{ft}$

50 Canadensis, $11 / 2$ to $2 \mathrm{ft}$.

125 Canadensis, 2 to $3 \mathrm{ft}$

25 Canadensis, 3 to $4 \mathrm{ft}$

40 Canadensis, 5 to $6 \mathrm{ft}$

25 nigra laciniata, 3 to $4 \mathrm{ft}$ -

75 nigra laciniata, 4 to $5 \mathrm{ft}$

10 nigra laciniata, 5 to $6 \mathrm{ft}$

125 racemosus (pubens), red-berried, $11 / 2$ to $2 \mathrm{ft}$...

150 racemosus (pubens), red-berried, 2 to $3 \mathrm{ft}$.......

300 racemosus (pubens), red-berried, 3 to $4 \mathrm{ft}$............

125 racemosus (pubens), red-berried, 4 to $5 \mathrm{ft}$..........

50 racemosus (pubens), red-berried, 5 to $6 \mathrm{ft}$...............

\section{SPIRAEA}



2465 Anthony Waterer, dwarf, pink, $11 / 2$ to $2 \mathrm{ft}$.

165 Anthony Waterer, dwarf, pink, 2 to $2 \mathrm{r} / 2 \mathrm{ft}$........

150 arguta, 2 to $3 \mathrm{ft}$.

350 arguta, 3 to $4 \mathrm{ft}$.

100 Bumalda, 1 to $1 \mathrm{t} / 2 \mathrm{ft} \ldots \ldots \ldots \ldots$

175 Bunialda, $1 \mathrm{r} / 2$ to $2 \mathrm{ft}$

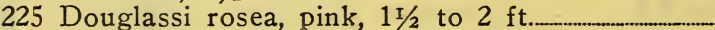

675 Douglassi rosea, pink, 2 to $3 \mathrm{ft}$..

800 Froebelli, pink, 2 to $2 \mathrm{r} / 2 \mathrm{ft}$.

1000 Froebelli, pink, $2 \frac{1}{2}$ to $3 \mathrm{ft}$.

Froebelli is a little stronger grower than Anthony Waterer and blooms two weeks earlier. Very desirable.

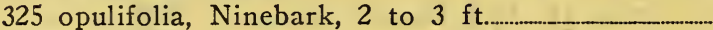

525 opulifolia, Ninebark, 3 to $4 \mathrm{ft}$

100 pulifolia Nineark, 4 to $5 \mathrm{ft}$

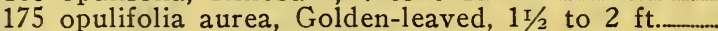

50 opulifolia aurea, Golden-leaved, 2 to $3 \mathrm{ft}$.

325 opulifolia aurea, Golden-leaved, 3 to $4 \mathrm{ft}$.................

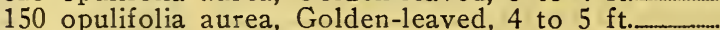

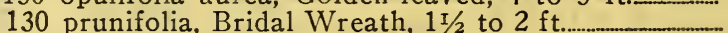

147 prunifolia, Bridal Wreath, 2 to $3 \mathrm{ft}$

2350 prunifolia, Bridal Wreath, 3 to $4 \mathrm{ft}$.....................

50 sorbifolia (Sorbaria), Ash-leaved, $11 / 2$ to $2 \mathrm{ft}$........

50 sorbifolia (Sorbaria), Ash-leaved, 2 to $3 \mathrm{ft}$.

150 sorbifolia (Sorbaria), Ash-leaved, 3 to $4 \mathrm{ft}$..........

10 sorbifolia (Sorbaria), Ash-leaved, 4 to $5 \mathrm{ft}$.........

40 Thunbergii, dwarf, white, 1 to $1 \mathrm{t} / 2 \mathrm{ft}$.

5.00 
THOMAS B. MEEHAN CO., DRESHER, PA., BULLETIN NO. 4

\section{SPIRAEA-(Continued)}

2300 Thunbergii, dwarf, white, 2 to $3 \mathrm{ft}$

150 Thunbergii, dwarf, white, 3 to $3 \frac{1}{2} \mathrm{ft}$.

3500 Van Houttei, white, $11 / 2$ to $2 \mathrm{ft}$.

5200 Van Houttei, white, 2 to $3 \mathrm{ft}$.

2359 Van Houttei, white, 3 to $4 \mathrm{ft}$.

STEPHANANDRA

25 flexuosa, $11 / 2$ to $2 \mathrm{ft}$

75 flexuosa, 2 to $3 \mathrm{ft}$

SYMPHORICARPOS-Snowberry-Coralberry

280 racemosus, Snowberry, $1 \mathrm{I} / 2$ to $2 \mathrm{ft}$.

120 racemosus, Snowberry, 3 to $4 \mathrm{ft}$.

75 racemosus mollis, large, white-fruited, $11 / 2$ to $2 \mathrm{ft}$.

850 racemosus mollis, large, white-fruited, 2 to $3 \mathrm{ft}$.

200 racemosus mollis, large, white-fruited, 3 to $4 \mathrm{ft}$.

80 vulgaris, Coralberry, 2 to $3 \mathrm{ft}$.

95 vulgaris, Coralberry, 3 to $4 \mathrm{ft}$.

\section{SYRINGA-Lilac}

170 Rothomagensis, Persian purple, $1 \frac{1}{2}$ to $2 \mathrm{ft}$.........

1050 Rothomagensis, Persian purple, 2 to $3 \mathrm{ft}$..

850 Rothomagensis, Persian purple, 3 to $4 \mathrm{ft}$..............

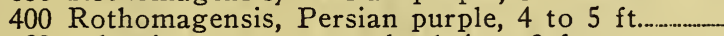

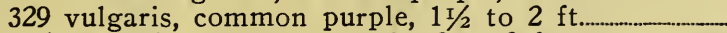

485 vulgaris, common purple, 2 to $3 \mathrm{ft}$.



225 vulgaris alba, common white, 2 to $3 \mathrm{ft}$

13 vulgaris, TREE FORM, $11 / 2$ to $2 \mathrm{ft}$._.....................

4 vulgaris, TREE FORM, 2 to $3 \mathrm{ft}$.

5 vulgaris alba, TREE FORM, $11 / 2$ to $2 \mathrm{ft}$.................

4 vulgaris alba, TREE FORM, 2 to $3 \mathrm{ft}$

\section{NAMED LILACS}

These Lilacs are all two-year-old, bush form.

12 Belle de Nancy, double, satiny rose, $11 / 2$ to $2 \mathrm{ft}$.

120 Belle de Nancy, double, satiny rose, 2 to $3 \mathrm{ft}$....

7 Buffon, single, pink, $11 / 2$ to $2 \mathrm{ft}$.

17 Buffon, single, pink, 2 to $3 \mathrm{ft}$.

7 Buffon, single, pink, 3 to $4 \mathrm{ft}$.

$2 \mathrm{ft}$

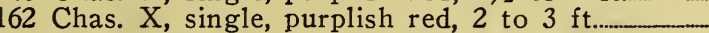

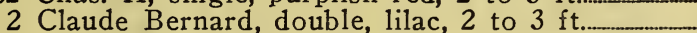

10 Claude Bernard, double lilac, 3 to $4 \mathrm{ft}$

19 Coerulea superba, single, blue, $11 / 2$ to $2 \mathrm{ft}$...........

19 Coerulea superba, single, blue, 2 to $3 \mathrm{ft}$.......................

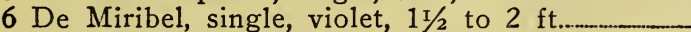

5 De Miribel, single, violet, 2 to $3 \mathrm{ft}$........

5 Diderot, single, red, $11 / 2$ to $2 \mathrm{ft}$.

7 Diderot, single, red, 2 to $3 \mathrm{ft}$.

196 Dr. Masters, double, clear lilac, $11 / 2$ to $2 \mathrm{ft}$._-

73 Dr. Masters, double, clear lilac, 2 to $3 \mathrm{ft}$

12 Dr. Masters, double, clear lilac, 3 to $4 \mathrm{ft}$.

2 Ellen Wilmott, double, white, $11 / 2$ to $2 \mathrm{ft}$

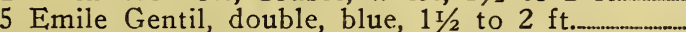

2 Emile Gentil, double, blue, 2 to $3 \mathrm{ft}$.

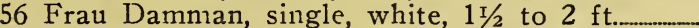

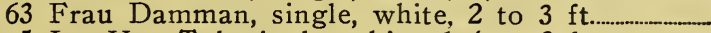

5 Jan Van Tol, single, white, $11 / 2$ to $2 \mathrm{ft}$...............

7 Jan Van Tol, single, white, 2 to $3 \mathrm{ft}$.

$89 \mathrm{Md}$. Abel Chatney, double, white, $11 / 2$ to $2 \mathrm{ft}$....

97 Md. Abel Chatney, double, white, 2 to $3 \mathrm{ft}$.

$35 \mathrm{Mme}$. Casimir Perier, double, white, $11 / 2$ to $2 \mathrm{ft}$.

72 Mme. Casimir Perier, double, white, 2 to $3 \mathrm{ft}$.......

39 Marie Legraye, single, white, $11 / 2$ to $2 \mathrm{ft}$.................

60 Marie Legraye, single, white, 2 to $3 \mathrm{ft}$.

4 Marechal Lanner, double, violet, $11 / 2$ to $2 \mathrm{ft}$.

38 Marechal Lanner, double, violet, 2 to $3 \mathrm{ft}$..........

3 Marechal Lanner, double, violet, 3 to $4 \mathrm{ft}$.

25 Mirabeau, single, lilac, $1 \frac{1}{2}$ to $2 \mathrm{ft}$.

12 Mirabeau, single, lilac, 2 to $3 \mathrm{ft}$

6 Mirabeau, single, lilac, 3 to $4 \mathrm{ft}$.

(1) $2 \mathrm{ft}$

41 Mont-Blanc, single, white, 2 to $3 \mathrm{ft}$.

3 Mont-Blanc, single, white, 3 to $4 \mathrm{ft}$

2 Pascal, single. lilac, 2 to $3 \mathrm{ft}$.

12 Pascal, single, lilac, 3 to $4 \mathrm{ft}$.

Prest. Faillieres, double, light lilac, 2 to $3 \mathrm{ft}$......

60 Prest. Grevy, double, blue, $11 / 2$ to $2 \mathrm{ft}$.

55 Prest. Grevy, double, blue, 2 to $3 \mathrm{ft}$

21 Prest. Viger, double, bluish lilac, $1 \frac{1}{2}$ to $2 \mathrm{ft}$......

46 Prest. Viger, double, bluish lilac, 2 to $3 \mathrm{ft}$.........

33 Princess Alexandra, single, white, $11 / 2$ to $2 \mathrm{ft}$.....

28 Princess Alexandra, single, white, 2 to $3 \mathrm{ft}$

9 Rubra Insignis, single, deep reddish purple, 2 to $3 \mathrm{ft}$. 
THOMAS B. MEEHAN CO., DRESHER, PA., BULLETIN NO. 4

\section{TAMARIX}

Per 10 Per 100

175 Africana, $1 \mathrm{t} / 2$ to $2 \mathrm{ft}$

1.65

13.00

325 Africana, 2 to $3 \mathrm{ft}$.

75 Africana, 3 to $4 \mathrm{ft}$

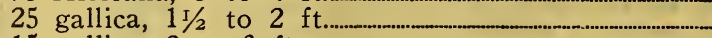

15 gallica, 2 to $3 \mathrm{ft}$.

$\begin{array}{ll}2.00 & 16.00 \\ 2.50 & 20.00\end{array}$

ULMUS-EIm

500 Americana, 6 to $8 \mathrm{ft}$.

500 Americana, 8 to $10 \mathrm{ft}$.

$\begin{array}{ll}2.50 & 20.00 \\ 1.65 & 13.00\end{array}$
VIBURNUM

8 cassinoides, $1 \mathrm{I} / 2$ to $2 \mathrm{ft}$.

15 cassinoides, 2 to $3 \mathrm{ft}$.

1000 dentatum, Arrow-wood, $11 / 2$ to $2 \mathrm{ft}$

750 dentatum, Arrow-wood, 2 to 3

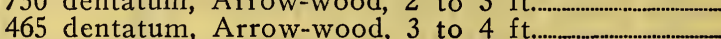

$j 65$ dentatum, Arrow-wood, 4 to $5 \mathrm{ft}$

25 Japonicum, $11 / 2$ to $2 \mathrm{ft}$

65 Japonicum, 2 to $3 \mathrm{ft}$

5 Japonicum, 3 to $3 \mathrm{x} / 2 \mathrm{ft}$.

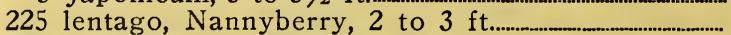

400 lentago, Nannyberry, 3 to $4 \mathrm{ft}$

50 lentago, Nannyberry, 4 to $5 \mathrm{ft}$.

2000 opulus sterilis, Common Snowball, $11 / 2$ to $2 \mathrm{ft}$...

1060 opulus sterilis, Common Snowball, 2 to $3 \mathrm{ft}$.........

225 plicatum, Japanese Snowball, $11 / 2$ to $2 \mathrm{ft}$.

400 plicatum, Japanese Snowball, 2 to $3 \mathrm{ft}$....

850 plicatum, Japanese Snowball, 3 to $4 \mathrm{ft}$.....................

250 tomentosum, $11 / 2$ to 2 ft

1200 tomentosum, 2 to $3 \mathrm{ft}$.

50 tomentosum, 3 to $4 \mathrm{ft}$

VINCA-Periwinkle

75 minor, 1 year

2.00

13.00

\begin{tabular}{l}
$6.50 \quad 60.00$ \\
\hline
\end{tabular}

$11.50 \quad 100.00$

$17.50 \quad 150.00$

WALNUT-See Juglans

WEIGELA

100 arborea, light pink, 3 to $4 \mathrm{ft}$

3.50

4.50

$1.85 \quad 15.00$

$2.50 \quad 20.00$

$3.50 \quad 30.00$

$4.50 \quad 40.00$

$5.00 \quad 45.00$

$6.00 \quad 50.00$

$3.50 \quad 30.00$

$4.50 \quad 40.00$

$5.50+50.00$

$3.00 \quad 25.00$

$4.00 \quad 35.00$

$4.00 \quad 35.00$

$5.00 \quad 45.00$

$6.00 \quad 55.00$

$3.00 \quad 25.00$

30.00

40.00

8.00

550 candida, white, 2 to $3 \mathrm{ft}$

60 candida, white, 3 to $4 \mathrm{ft}$..

17 candida, white, 4 to $5 \mathrm{ft}$.

15 Desboisei, dark pink, 3 to $4 \mathrm{ft}$

20 Desboisei, dark pink, 4 to $5 \mathrm{ft}$.

20 Desboisei, dark pink, 5 to $6 \mathrm{ft}$

25 Eva Rathke, crimson, 2 to $3 \mathrm{ft}$................................. $\quad 3.00$

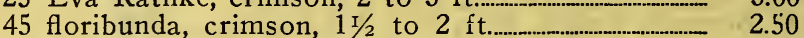

150 floribunda, crimson, 2 to $3 \mathrm{ft}$

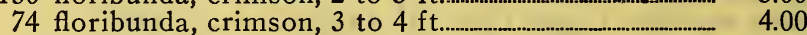

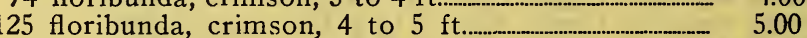

25 nana variegata, 2 to $3 \mathrm{ft}$

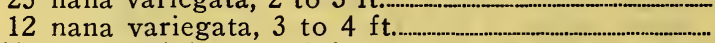

650 rosea, pink, 2 to $3 \mathrm{ft}$

1948 rosea, pink, 3 to $4 \mathrm{ft}$.

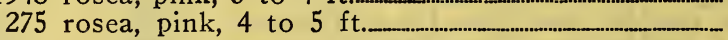

WILLOW-See Salix

WISTERIA

25 sinensis, Chinese purple, from seed, 2 to $3 \mathrm{ft}$.......

15 sinensis, Chinese purple, from seed, 3 to $4 \mathrm{ft........}$

88 sinensis alba, Chinese white, grafts, 2 to $3 \mathrm{ft} . . . . .$. YUCCA-Adam's Needle, Spanish Bayonet

560 filamentosa, 3 year

20.00

20.00

25.00

35.00

25.00

20.00

25.00

35.00

45.00

20.00

4.00

2.00

2.00

16.00

20.00

$3.50 \quad 30.00$

\section{DUTCH GRANULATED PEAT}

Finest material for propagating purposes or for mixing with soil to loosen it up and add humus. Especially is this necessary where ericaceous plants are propagated. We are handling only the very best quality. All brands are not alike in quality. Some brands appear to be cheaper, but there is a great difference in quantity packed in bale. Most cheap brands weigh from 132 to $176 \mathrm{lbs}$. per bale. Our bales weigh 200 to $220 \mathrm{lbs}$. Therefore in our bales you get a greater quantity of material.

1 to 9 bales at $\$ 3.00$ per bale; 10 bales and up, $\$ 2.90$ per bale.

\section{NURSERY SUPPLIES}

We carry in stock a full line of Canes, Spades, Pruning and Budding Knives, Pruning Shears and Tree Callipers. Write for price list.

\section{RAFFIA}

We are direct importers of Raffia and supply most of the nurseries in the country. "Red Star," "XX Superior" and "A. A. Westcoast."

Write for price list.

\section{Thomas B. Meehan Co.}

